\title{
MAJOR CHOICE DETERMINANTS. COMPARATIVE ANALYSIS OF THE PUBLIC MANAGEMENT MAJOR AT THE INSTITUTE OF PUBLIC AFFAIRS OF THE JAGIELLONIAN UNIVERSITY
}

\section{MAŁGORZATA MARZEC}

Jagiellonian University Department of Management and Social Communication Jagiellonian University, Institute of Public Affairs, POLAND e-mail: malgorzata.marzec@uj.edu.pl

\section{RECEIVED \\ ACCEPTED \\ JEL \\ CLASSIFICATION}

KEYWORDS

ABSTRACT
26 July 2017

15 December 2017

$A 20, A 23,121,123, I 26$

major choice motives, public management, Poland

The main aim of this article is to present factors behind a choice of the academic major - management with the field of study - management in the public and non-governmental sector at the Institute of Public Affairs of the Jagiellonian University (IPA JU). The article presents motives which may be a basis of a decision on undertaking higher education at any major and at the major - management with the field of study - management in the public and non-governmental sector. An attempt was made to compare motives behind a choice of various majors. The following questions were asked: What motives are the students beginning higher education guided with? Do the students starting their education at the IPA JU have the same motives as students starting education at other majors? The article was written based on the literature review, widely available research and analyses of research carried out among students who began studies at the IPA JU in 2008-2016.

\section{Introduction}

The market for higher education educational services is very competitive. It is influenced by globalization, internationalization, but also by increasingly high demands and awareness of students. Universities should better understand the needs and expectations of their students. It is extremely important to build relationships between potential students and the university. In order to be able to establish relationships with potential students, the 
decision-making process, which is followed by the candidates for studies, should be well recognized (Vrontis, Thrassou, Melanthiou, 2007, p. 987). Secondary school pupils who are about to take their school-leaving exams find it difficult to make decisions concerning a major which influence their future professional life. Applicants get information which is difficult to compare and check. It is worth noticing that some choices of majors are made under the influence of factors regardless a college. However, the knowledge of decision-making processes allows students to acquire, to shape the educational offer, to influence the market behavior of potential candidates for studies and to build relationships (Drapińska, 2010, p. 48). Secondary school students ask such and many others questions before they make a decision concerning selection of a college and major. Taking education-related decisions is a complex process based on multiple factors. These are: personality, cognitive, emotional determinants as well as economic and social factors (Jakubowska-Baranek, 2003). Some analyses indicate significance of such factors as: intellectual development, relevant training to perform a well-paid occupation, raising a social status through a university diploma, extending interests (Jarecki, 2015). Setting general factors which are decisive for choosing majors with those which are significant for choosing a major at the IPA JU seems to be interesting. The paper applies results of the studies carried out by the Main Statistical Office and results of research carried out in cycles among students who begin their studies at the IPA JU.

\section{Motives behind a decision on a major - analysis of literature and available Polish research}

Raising competences, including broadening of knowledge, development of interests and acquisition of professional experience as well as shaping personality which can be useful in professional work should be the main aim of studying (Polańska, 2017, p. 134). Studies should be one of the elements of the educational path and training to perform professional work. Motives behind a decision concerning selection of a college and major depend on many variables. Variability of motives depends both on the future students' interests as well as assessment of prospective possibilities of finding a job after completion of a college. It is also related to knowledge, skills, abilities and plans for future. Taking educational decisions may be also shaped accidentally, depending on the parents' financial situation, place of living, influence of friends. Attractiveness of a particular major and a city where studies are held is also crucial. Students who start their education wish to spend their youth as interesting as possible. Acquisition of knowledge and qualification indispensable in the future professional work may not be as important. Higher education is not only fashionable but also necessary with regard to the requirements of the labour market. Unfortunately, for some people the aim of studying is not only acquisition of knowledge and skills but obtaining a document which is necessary to enter the job market (Walczak, 2017, pp. 157-160).

Education in a college enables raising competences which are identified also with qualifications, experience and personal features. We may find many definitions of competences in the subject literature. According to Oleksyn, competences should be defined as "education, experience and skills, talents and predispositions (other) psychophysical properties and a conduct expected from employers and important for a given occupation" (Oleksyn, 1997, p. 23). The discussed definition extensively defines competences, which the students may develop during studies.

Human conduct aims at adjustment to the environment (Franken, 2005) There are numerous theories of motivation. It is worth to indicate the following ones, i.e. a subject model, humanist model and cognitive model. The first model - the subject one indicates the meaning of a stimulus as a source of motivation. The second model - the humanist one, assumes that motivation is based on inner processes without participation of external factors. 
External stimuli may only influence the conduct. The cognitive model emphasises formation of cognitive processes which may influence reactions. Psychologists claim that processing of information is the basis of motivation in action. A manner in which secondary school students process information influences behaviour with regard to major choice decisions. (Kucharski, Ligocka, 2012, pp. 45-47) Selection of the educational path and decision with this respect is a complex process. A personality, cognitive and emotional factors including social and material status are significant among the motives for such a decision. The young people who make a decision concerning a major take into account cognitive reasons which determine a practical aspect of the university degree. Decisions are made based on the perspective of finding a job on the market and are related to the social position. Studies do not have to be compliant with the interests but should ensure a good position on the job market through a well-paid job.

Interesting results of research concerning educational paths of Poles were presented in the study by the Main Statistical Office on Selection of an educational path and professional situation of Poles from 2013 (Wybory..., 2013). Choice of a college is mainly influenced by the possibility of education in the expected profession/education profile and a suitable curriculum and high level of teaching. Availability of a college with regard to the place of living and suitable hours of classes is of less significance. The investigated people who make their decisions on the educational profile, focus mainly on the possibility of finding a job, additionally compliant with their interests. Possibility of finding any job and finding a well -paid job is of less significance. Raising competences or a possibility of promotion is also significant for the selection of the major (Wybory..., 2013, p. 80).

There are many studies which present how the educational decisions are made and analyses which describe motivations behind decisions taken by secondary school graduates. The most often - three dominating stages of the studies choice process can be distinguished, i.e. a stage related to selection of the educational path, stage of searching for information on possible choices and the stage of decision making.

In the first stage, secondary school students make a decision with regard to a specific educational path related to a given major. Here, social and economic factors, family circumstances, personality features of an applicant, specificity of the job market and employers' requirements are predominant. This stage is completely independent from the college itself. In this stage, young people indicate general preferences concerning the major, a school, where they can study, taking into consideration such factors as distance from the place of living, expected costs of studying. The second stage is related to searching for information concerning majors and colleges. In this stage young people actively or passively search for information on the variants of a decision. The third stage includes the process of decision making on a selection of one or several colleges and one or several majors. Here, great rationality of undertaken decisions, based on calculation of costs and advantages, is indicated. However, it is emphasised that rationality is limited with socio-economic factors or culture ones. The future path of a professional career and the level of remuneration and prestige are a basic criterion of choice (Pawlak, Grzesiuk, 2015, pp. 93-106).

Colleges may effectively influence the process of decision-making in its second and third stage. These schools may actively participate in transferring information on offered majors, rules of recruitment, conditions of studying, curricula. Based on the research by A.F. Cabrera and S.M. Nasa (2000, pp. 9-19) one may distinguish three basic groups of factors of a decision on the major and school. They include: 1) individual features, including professional aspirations and competences and skills of secondary school graduates; 2) environment, including socio-economic status and parents' support, 3) expectations concerning the school itself including quality - school's reputation, academic life (interesting youth), major choice possibility, distance from the place of living. 
It is also worth emphasising that many researchers indicate also the meaning of institutional properties of a college. Places where classes are held, variability of offered majors, available infrastructure (e.g. dormitories, library, sport gyms etc.), a city where the school operates, and recruitment procedure are important (Flint, 1992, pp. 697-701).

Except for analyses of the national statistical research (including the Main Statistical Office on educational paths) one may find studies prepared by particular colleges on recruitment at various majors. The investigated students indicate inter alia: interests and skills, environmental determinants (including family, lifestyle), personal experiences with people, opinions of other students, as well possibility of finding a job after school, attractive offer of foreign languages teaching, availability of scholarships abroad and specialization and possibility of using scientific materials (Lalak, Skiba, 2010; Łapiński, 2006, p. 99; Górniak, 2014, p. 23).

Slightly different results of research concerning motives behind a decision on a major is presented in the PWC Report on (Un) conscious professional choices from June 2014 ((Nie)świadome wybory..., 2014) Majority of investigated secondary school pupils claims that ambitions and passion are an important or prevailing factor in selection of a major. Finding a job after college is also significant. The school reputation is the third important factor. Location of a school is less significant. Popularity of a given major, family tradition and friends' suggestions are less important. According to the report, a conclusion can be made that passion and ambition, then, a possibility of finding a job after school are the most important factors for the major choice. However, one should remember that people who start education in a college make a major-related decision based on the current situation on the job market, which may change in the course of studies. Selection of a major as early as in the secondary school may not be adjusted to the situation on the job market after the studies are completed. The schools' reputation may be an important factor. Well - known and recognized colleges are assessed higher by applicants. Location - the place where classes are held and popularity of the major are less important for the choice. Young people make educational decisions under slight influence of family traditions or based on the friend's opinion ((Nie)świadome wybory..., 2014)

Management is still a popular major among secondary school graduates. Information presented by the Ministry of Science and Higher Education on the results of recruitment to colleges for 2015/2016 academic year shows that every tenth applicant chooses management. Law and informatics are more popular (16\%) (Informacja o wynikach..., 2015).

Taking into consideration changes which take place on the educational market as well as competition with regard to offered majors, the IPA JU undertakes actions aiming at determination of major choice determinants. The undertaken measures aim at tracing changes in the applicant's profile and indication of possible promoting actions of the IPA JU.

\section{Case studly - determinants of choice of the IPA JU majop}

Each year the Institute of Public Affairs carries out a research among students who begin education at the management major with the field of study in management in the public and non-governmental sector. The aim of the research is collection of information on sources of information on the IPA UJ, carried out majors and factors which decide on the choice of a college.

Students who start their education at the IPA JU declare that the school's reputation, city (Kraków) and curriculum are decisive. Moreover, students who started their education in 2016 were driven with the possibility 
of obtaining good job after graduation and qualifications to work in the public sector. Intellectual development and obtaining a diploma of a popular university is also important. A random choice of the major and the second-major possibility at the IPA JU seems to be surprising. In 2008-2016 one may report a change in the meaning of several factors which decide on the major choice. One may observe decrease of the meaning of determinants i.e. satisfaction of interests related to the public sector and management, possibility of finding a well paid profession after completion of studies, possibility of obtaining a diploma from the JU, possibility of finding a job in the public sector. The increase of significance of other factors, i.e. extension of intellectual aspirations and coincidence is worth indicating. As one can observe, on one hand, students do not make decisions only on the basis of possibilities of finding a job after a college but they would also like to acquire knowledge related to the public sector and management. Unfortunately, a significant increase of the meaning of "incident" at selection of a college and a decrease of the significance of an interesting and fashionable major seems to be worrying.

Persons who choose studies at the major carried out by the IPA JU do not differ from other applicants. A possibility of finding a well-paid job and not necessarily in the public sector is a prevailing factor with regard to the selection of a major. A reputation of a school which guarantees a specific level of education, teaching curricula and lecturers are also important.

\section{Conclusions}

Colleges face a necessity of adjusting an offer of studies to students and to the labour market needs. Colleges fight the problem of a demographic low and the problem of adjusting education of students prepared to changing requirements of the labour market. Majors must be attractive for young people, guarantee a relevant level of acquired education and effectively shape strategies of obtaining students. Decisions made within the scope of selection of studies are related to the planning of professional future of employees. Secondary school leaving pupils undertake decisions on the major based on several factors. A possibility of finding a job, quality of a college or a major and satisfaction of intellectual aspirations are crucial. Teenagers must make decisions related to their education which affect their future situation on the job market. It would be the best if the major was related to the young people's interests. Then, a cognitive curiosity would precondition the use of the students' potential to learning which is compliant with their interests. However, practical aspects, such as training to carry out a given profession, prevail at a selection of a given major. Students who start studies at the IPA JU do not differ from other applicants.

\section{References}

Cabrera, A., La Nasa, S. (2000). Understanding the College-Choice Process. New Directions for Institutional research, 412.

Drapińska, A. (2010). Zachowania klientów na rynku usług edukacyjnych szkół wyższych. Zeszyty Naukowe Uniwersytetu Szczecińskiego, 594. Ekonomiczne Problemy Usług, 54, 47-67.

Flint, T. (1992). Parental and Planning Influences on the Formation of Student College Choice Sets. Research in Higher Education, $6(33)$.

Franken, R. (2005). Psychologia motywacji. Gdańsk: Gdańskie Wydawnictwo Psychologiczne.

Górniak J. (2014). Bilans potrzeb pracodawców i możliwości rynku pracy w sytuacji dekoniunktury. In: J. Górniak (ed.), Kompetencje Polaków a potrzeby polskiej gospodarki. Raport podsumowujący IV edycję badań BKL z 2013 roku (pp. 19-46). Warszawa: Polska Agencja Przedsiębiorczości, Warszawa.

Informacja o wynikach rekrutacji na studia na rok akademicki 2015/2016 w uczelniach nadzorowanych przez MNiSW (2015). Retrieved from: https://www.nauka.gov.pl/g2/oryginal/2015_12/27a9652393f0ad67aa93f16b04dd9127.pdf. 
Jakubowska-Baranek, J. (2003). Czasy transformacji ustrojowej a motywy podejmowania nauki na uniwersytecie oraz wyboru kierunku studiów przez młodzież. In: E. Idzikowski, E. Narkiewicz-Niedbalec, M. Zielińska, E. Papiór (eds.), Młodzież polska w nowym ładzie społecznym. Zielona Góra: Uniwersytet Zielonogórski.

Jarecki, W. (2015). Motywacje przy podejmowaniu studiów wyższych ekonomicznych. Annales. Etyka w życiu gospodarczym, 3 (18), 133-141.

Kucharski, A., Ligocka, M. (2012). Maturzyści o motywach i źródłach poszukiwania informacji dotyczących studiów. Opuscula Socologica, 1 (1).

Lalak, D., Skiba, W. (2010). Profil społeczno-motywacyjny osób podejmujacych studia na kierunku praca socjalna. Badania porównawcze. Prace Instytutu Profilaktyki Społecznej i Resocjalizacji, 16.

Łapiński, W. (2006). Oczekiwania studentów wobec studiów magisterskich z dziedziny zarządzania a stopień ich zaspokojenia na przykładzie Wydziału Zarządzania UW. Studia i Materiały Wydziału Zarządzania Uniwersytetu Warszawskiego, 2.

(Nie świadome wybory zawodowe (2014). Raport PCW. Retrieved from: https://www.pwc.pl/pl/.../assets/wybory-zawodowe2014-raport-pwc.pdf (8.03.2017).

Oleksyn, T. (1997). Praca i płaca w zarządzaniu. Warszawa: Międzynarodowa Szkoła Menadżerów.

Pawlak, M., Grzesiuk, K. (2015). Czynniki wpływające na wybór studiów na przykładzie maturzystów z województwa lubuskiego. Przedsiębiorczość i Zarządzanie, XV (8/II).

Polańska, A. (2017). Uczenie studentów krytycznego (koncepcyjnego) myślenia priorytetowym zadaniem dydaktyki szkoły wyższej. Retrieved from: www.wsaib.pl/files/dziekanat/uczenie\%20_krytycznego_myslenia.doc (8.03.2017).

Polańska, A. (2017). Uczenie studentów krytycznego (koncepcyjnego) myślenia priorytetowym zadaniem dydaktyki szkoły wyższej Retrieved from: www.wsaib.pl/files/dziekanat/uczenie\%20_krytycznego_myslenia.doc (8.03.2017).

Walczak, W. Wpływ kultury organizacyjnej na kształtowanie postaw i poziom zaangażowania studentów Retrieved from: https://www. academia.edu/22957787 (8.03.2017).

Wybory ścieżki edukacyjnej a sytuacja zawodowa Polaków (2013). Warszawa: GUS.

Vrontis, D., Thrassou, A., Melanthiou, Y. (2007). A contemporary higher education student-choice model for developed countries. Journal of Business Research, January.

Cite this article aS: Marzec, M. (2018). Major choice determinants. Comparative analysis of the public management major at the Institute of Public Affairs of the Jagiellonian University. European Journal of Service Management, 1 (25), 173-178. DOI: 10.18276/ ejsm.2018.25-21. 